\title{
Bemba Language
}

National Cancer Institute

\section{Source}

National Cancer Institute. Bemba Language. NCI Thesaurus. Code C153855.

A Niger-Congo Bantu language spoken primarily in north-eastern Zambia by the Bemba people. 